\begin{tabular}{c} 
Volume and Issues Obtainable at Center for Sustainability Research and Consultancy \\
Review of Politics and Public Policy in Emerging Economies \\
ISSN: $2708-3829$ \& (E): $2708-356 X$ \\
Volume 2: No. 2, December 2020 \\
CSRC \\
Journal homepage: $\underline{\text { www.publishing.globalcsrc.org/rope }}$ \\
\hline
\end{tabular}

\title{
How does Debt Financing affect Financial Performance? A Study of Transport Companies listed in Pakistan
}

\author{
*Ulfat Abbas, Lecturer, Institute of Southern Punjab Multan \\ Sohail Aziz, Lecturer, Institute of Southern Punjab Multan \\ Samina Khan, Lecturer, Institute of Southern Punjab Multan \\ *Corresponding author's email: ulfat.abbas@iub.edu.pk
}

ARTICLE DETAILS
History
Revised format: May 2020
Available Online: : Jun 2020

Keywords

Debt financing

Companies' performance

Transport Sector

JEL Classification

C21, C42, D85

\begin{abstract}
Purpose: The purpose of this paper investigates the impact of debt financing on airline's (transport) sector performance of Pakistan.
\end{abstract}

Design/Methodology/Approach: We gathered the data from secondary sources. In this study, we used a data sample of 11 years from 2008-2018 by using companies annual reports. Due to unavailability of data, only 3 transport companies have been taken for analysis. The software which we used in analysis is SPSS (Statistical Package for Social Science).

Findings: The findings of the study suggests that there is opposite relationship between debt financing and financial performance of airlines. Debt is measured from three ratios, short term debt to total assets, long term debt to total assets and total debt to total assets ratio. For the measurement of performance, we used return on assets and earnings per share. We concluded on the basis of findings that the companies should focus on retained earnings which is cheaper source of finance and use less level of debt. As the more level of debt use by the companies, the performance of companies' decrease.

Implications/Originality/Value: There is only one study is available in Pakistan which used transport sector in Pakistan in debt financing context.

(C) 2020 The authors, under a Creative Commons Attribution-Non Commercial 4.0

Recommended citation: Abbas, U. Aziz, S. and Khan, S. (2020). How does Debt Financing affect Financial Performance? A Study of Transport Companies listed in Pakistan. Review of Politics and Public Policy in Emerging Economies, 2 (2) 75-84.

\section{Introduction}

The decisions about capital structure plays a very important for every type of business. Each type of organization usually involved in determining the appropriate capital structure where there is minimum cost. It consists of debt and equity mixture. This is management decision whether to take the equity from shareholders or take the debt from third party. Each industry characteristics are different from other industry and change the capital structure according to the industry requirement. Optimal equity and debt mixture increase the value of company (Damodaran, 2001). 
Airlines industry plays an important role for economic development and providing employment opportunities. This industry includes the services of cargo and passengers. As compare to cargo services, passenger transportation provides the major income to airlines industry (Bratlie, 2012). Airlines industry is considered the largest industry of the world. The importance of this industry has increased due to its globalization. There is need of huge investment for this industry and also need to comply strict rules and regulation. So this industry is capital intensive because large investment needed for purchase of aircrafts. Generally the performance of airline industry is not good due to high cost and revenues are not sufficient to cover the cost. Pakistan airlines industry is also in loss. Due to debt obligations companies have to bear a lot of interest cost and ultimately deteriorating the performance of airline industry. If a country has no proper transport system then that state cannot develop and faces a lot of problems of transportation.

Airline industry provides the opportunity to the people to travel such places which are thought as impossible. This industry is energy intensive industry due to high fuel consumption. Due to higher competition cause the airline industry to focus on the lowering the costs and increase the productivity. So to take the benefit of economies of scale, there were a lot of acquisitions and mergers in airline industry.

The purpose of the company is to uplift the shareholder value and it will only increase when management takes such decisions in which cost of debt and equity minimum. The source of finance of a company can be equity financing and debt financing. Capital structure is most significant for organizations because these are affecting the risk and return of shareholders (Pandey, 2010). According to the research of Tomoiga (2014) mostly company's capital structure consists of $40 \%$ equity and 60\% debt. The financial crises of 2007-2008 also affected the airlines industry performance and also mixture of debt and equity affect the performance (Bjelicic, 2012). So there is a need to consider the optimal capital structure. The companies prefer to raise capital by internal sources than to use the debt or equity which are costly as compare to retained earnings.

This study investigates the debt financing impact on airlines industry performance in Pakistan and there is no any study conducted relating to debt financing impact on performance of airlines industry in Pakistan. So there is a need to analyze the connection between debt and financial performance in this sector in Pakistan. This paper will help in taking decisions relating to the investment in airlines industry. The findings of this study will be very helpful for managers of this industry relating to decisions about debt financing and also beneficial for shareholders to invest in this industry.

Following are the objectives of the study:

- To explore the association between short-term debt financing and financial performance of Airlines (transport) sector

- To investigate the association between long term debt financing and financial performance.

- To examine the relationship between total debt financing and financial performance.

- To suggest recommendations on the basis of findings.

\section{Literature Review}

In literature review we study the previous studies relating to the debt financing and performance of transport companies.

Khazaaleh (2017) analyzed the association between debt and the financial performance of airlines 
in Dubai. This covers the period 2010-2015. Data has been taken from secondary sources and annual company reports have been used. The study variables were utility, growth, development and style. The regression analysis of the Study Panel was used to verify the relationship between the variables. This study concluded that there is positive association between debt financing and profitability of firms.

Tomoiaga (2014) investigated the value of airline and capital structure. This study covers the entire world airline industry. The sample include in this study was 111 companies. In this study, they used multivariate analysis in transport sector. This concluded that there was association between company size and company value which is positive.

Bratlie and Jotne (2012) examined the causes which affect the capital structure of airline industry. 39 companies have been taken as sample. The econometric approach has been used. The study covered the period from 2000 to 2010 . Variables used in study were debts, leverage and sizes. The author recommended that there is opposite association between leverage and profitability of companies and there is positive significant association between firm size and leverage of transport sector.

Alahyari (2014) examined the connection between profitability and its' determinants in Turkish airlines. This study takes the data from 1994 to 2013. Data have been taken from secondary sources which is Datastream Software. Profitability has been taken as dependent variable while company size, growth opportunities, leverage, liquidity and tangibility of assets have been taken as explanatory variables. This study used panel data stream for data analysis. The findings suggested that there is negative but significant relationship among growth, liquidity and tangibility with financial performance. There is negative association among size and leverage with profitability of Turkish airlines. The study recommended that there is a need to decrease the tangibility and liquidity level in order to increase the profitability. The study can be extend by consider other independent variables and taking long period of time.

Capital structure are traditional theories by Miller and Modigliani, agency theory and pecking order theory.

In traditional theory tax factor has been ignored. At low level of debt, the return of equity holders is low and due to this WACC has decreased but as the level of debt has been increased then returns of shareholders increased and it will cause the increase in WACC. So the companies should choose the optimal capital structure where company's value is maximum and minimum cost of capital.

Figure 1: Capital Theories (Traditional Perspective): Cost Minimum Case

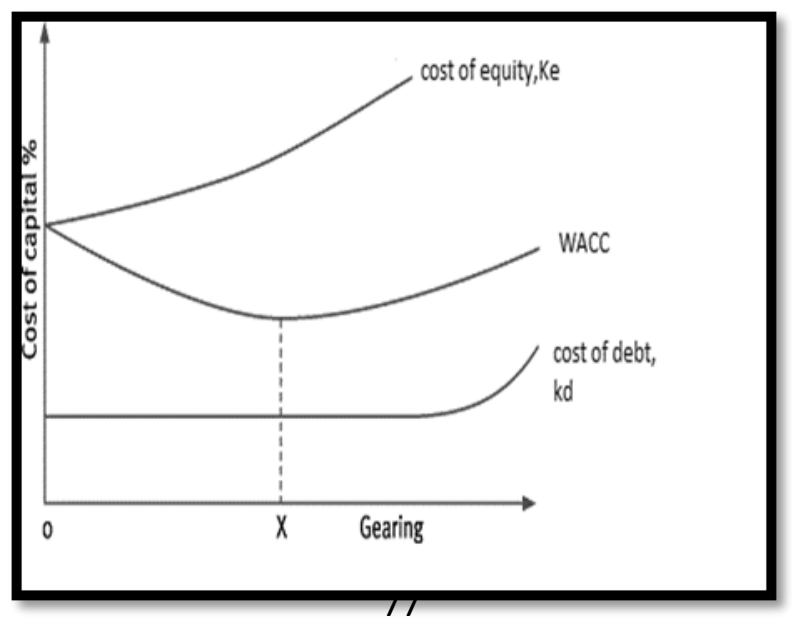


Ke is measure of cost of equity in cost of capital while

$\mathrm{Kd}$ is measure of cost of debt in cost of capital

Ko which is indicated by weighted average cost of capital which is shortly used WACC In the above figure at point $\mathrm{X}$ cost is minimum and company value is maximum.

Figure 2: Capital Structure Theory (Traditional Perspective): Regarding Firm's Value

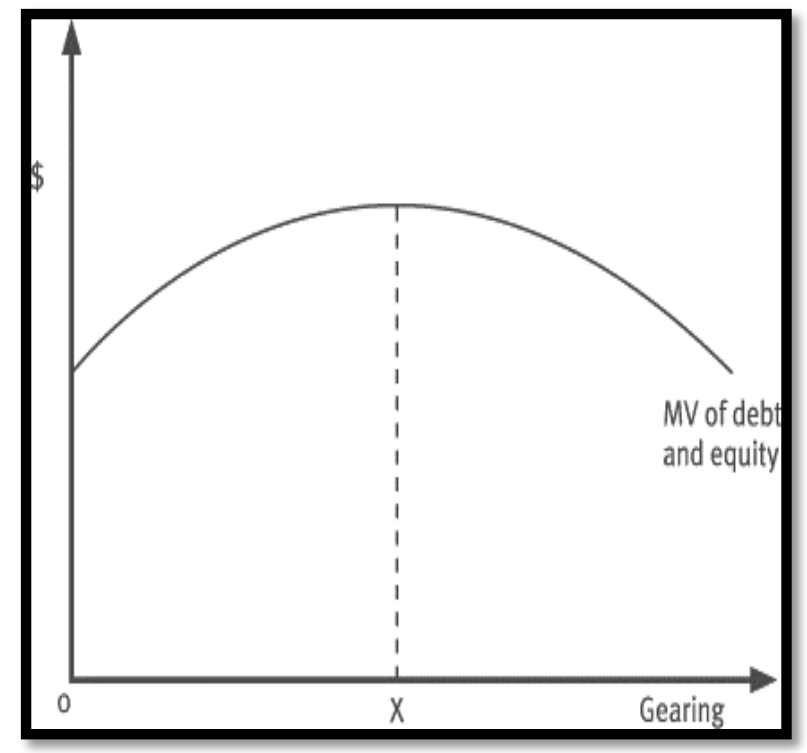

In the figure 2-point $\mathrm{X}$ is a point where company value is maximum.

Modigliani and Miller demonstrated in 1958, companies financial structure have no influence on the company value. This theory is irrelevant theory because debt structure of company has no influence on the value of company and ignore the tax effect.

In this scenario, both levered and unlevered firm's values are same.

$$
\mathrm{V}_{\mathrm{U}}=\mathrm{VL}
$$

Modigliani and Miller revised the theory in 1963 and consider the tax factor. This theory recognized that interest payments cause the tax benefits and reduce the cost of debt. This theory tells that as the company increase the level of debt the WACC has been decreased.

In 1961 Donaldson introduced the theory of pecking order which tells the least cost method of fund raising. The pattern of fund raising is as follows:

- Retained earnings

- Debt

- Equity

So the companies should firstly choose the retained earnings as a source of finance which is cheapest source as compare to debt and equity.

\section{Hypotheses}

Based on above theories discussed earlier and literature review, we develop these hypotheses. $\mathrm{H} 1$ : There is negative connection between financial performance and short term debt. $\mathrm{H} 2$ : There is negative association between financial performance and long term debt.

In the earlier studies of (Gaud et al. 2005, Daskalakis \& Psillaki, 2008; Titman \& Wessels, 1988) found the opposite association between debt and financial performance. Trade off theory states that financial distress has been reduced due to high profitability and companies increase the level of debt due to tax deductibility on payment of interest. So positive relationship between debt and profits (Frank and Goyal, 2009). 


\section{Methodology}

\section{Model Specification}

The model shows the relationship between performance and the debt. The following are the models.

Model 1: STD to TA and firm performance

$\mathrm{EPS}_{\mathrm{it}}=\beta_{0}+\beta_{1} \mathrm{STDTA}_{\mathrm{it}}+\beta_{2} \mathrm{FS}_{\mathrm{it}}+\mathrm{e}_{\mathrm{it}}$

Model 2: LTD to TA and firm performance

EPS $_{\text {it }}=\beta_{0}+\beta_{1}$ LTDTA $_{\text {it }}+\beta_{2}$ FS $_{\text {it }}+e_{\text {it }}$

Model 3: TD to TA and firm performance

$\mathrm{EPS}_{\mathrm{it}}=\beta_{0}+\beta_{1}$ TDTA $_{\mathrm{it}}+\beta_{2} \mathrm{FS}_{\mathrm{it}}+\mathrm{e}_{\mathrm{it}}$

Model 4: Short term debt ratio with financial performance

$\mathrm{ROA}_{i \mathrm{it}}=\beta_{0}+\beta_{1} \mathrm{STDTA}_{\mathrm{it}}+\beta_{2} \mathrm{FS}_{\mathrm{it}}+\mathrm{e}_{\mathrm{it}}$

Model 5: LTD to TA with financial performance

$\mathrm{ROA}_{i t}=\beta_{0}+\beta_{1}$ LTDTA $_{\text {it }}+\beta_{2} \mathrm{FS}_{\text {it }}+\mathrm{e}_{\mathrm{it}}$

Model 6: TD to TA with financial performance

$\mathrm{ROA}_{\text {it }}=\beta_{0}+\beta_{1} \mathrm{TDTA}_{\text {it }}+\beta_{2} \mathrm{FS}_{\text {it }}+\mathrm{e}_{\mathrm{it}}$

Where

Earnings per share $=$ EPS

Return on Assets = ROA

Short term debt to total assets $=$ STDTA

Long term debt to total assets= LTDTA

Total debt to Total Assets= TDTA

\begin{tabular}{|l|l|l|}
\hline Variable & Proxy & Measurements \\
\hline Earnings per share & EPS & Net income to no. of shares \\
\hline Return on Assets & ROA & Net income to total assets \\
\hline Short term debt ratio & STDTA & Short term debt to total assets \\
\hline Long term debt ratio & LTDTA & Long term debt to total assets \\
\hline Total debt ratio & TDTA & Total debt to total assets \\
\hline Firm size & FS & Natural log of total assets \\
\hline
\end{tabular}

\section{Data: Source and Sample}

For the collection of data, annual reports are used which published by airline industry. The data of this study has been taken from 2008 to 2017 . Due to unavailability of data there are only 3 companies of transport industry used in this analysis.

\section{Measurement of Variables}

The performance of companies is taken as dependent variable and is measured from ROA and EPS while STDTA, LTDTA and TDTA are taken as independent variables. Firm size is control variable which is measure from natural log of total assets.

\section{Results and Findings}

This section discusses the results and findings of the study.

\section{Descriptive Statistics}

The description of the variable data is shown in Table 1. The mean of EPS is 7.09 and -18.67 and 25.63 are minimum and maximum values. The standard deviation of the EPS is 12.95. The mean value of ROA is 0.11 and the minimum and maximum value are -0.30 and 0.70 . The standard deviation of ROA is 0.25 . STDTA means value is 0.43 and the minimum and maximum values are 0.07 and 1.18. The standard deviation of STDTA is 0.36 . 
LTDTA mean value is 0.36 and the minimum and maximum values are 0.00 and 0.87 , while the standard deviation is 0.27 . TDTA mean value is 0.78 and 0.08 and 2.02 are minimum and maximum values, while the standard deviation of TDAT is 0.58 . The mean value of firm size is 17.21 and the standard deviation is 1.45 .

Table 1: Descriptive Statistics of Key Variables

\begin{tabular}{|l|r|r|r|r|r|}
\hline \multicolumn{7}{|c|}{ Descriptive Statistics } & \multicolumn{1}{c|}{ Mean } & Std. Deviation \\
\hline & $\mathrm{N}$ & \multicolumn{1}{|c|}{ Minimum } & Maximum & 7.09 & 12.95 \\
\hline EPS & 32 & -18.67 & -30.63 & .11 & .25 \\
\hline ROA & 32 & -.30 & .70 & .43 & .36 \\
\hline STDTA & 32 & .07 & 1.18 & .36 & .27 \\
\hline LTDTA & 32 & .00 & .08 & .78 & .58 \\
\hline TDTA & 32 & 15.24 & 19.21 & 17.21 & 1.45 \\
\hline FS & 32 & & & &
\end{tabular}

\section{Correlation Matrix}

Correlation analysis used to check the association and strength between variables. Table 2 shows the association between variables.

\begin{tabular}{|c|c|c|c|c|c|c|c|}
\hline & & & & & & & \\
\hline \multirow{4}{*}{ EPS } & & & & & & & \\
\hline & Pearson Correlation & 1 & & & & & \\
\hline & Sig. (2-tailed) & & & & & & \\
\hline & $\mathrm{N}$ & 32 & & & & & \\
\hline \multirow[t]{3}{*}{ ROA } & Pearson Correlation & $.716^{* * *}$ & 1 & & & & \\
\hline & Sig. (2-tailed) & .000 & & & & & \\
\hline & $\mathrm{N}$ & 32 & 32 & & & & \\
\hline \multirow[t]{3}{*}{ STDTA } & Pearson Correlation & $-.638^{* *}$ & -.310 & 1 & & & \\
\hline & \begin{tabular}{|l|} 
Sig. (2-tailed) \\
\end{tabular} & .000 & .084 & & & & \\
\hline & $\mathrm{N}$ & 32 & 32 & 32 & & & \\
\hline \multirow[t]{3}{*}{ LTDTA } & Pearson Correlation & $-.789^{* *}$ & $-.537^{* *}$ & $.665^{* *}$ & 1 & & \\
\hline & Sig. (2-tailed) & .000 & .002 & .000 & & & \\
\hline & $\mathrm{N}$ & 32 & 32 & 32 & 32 & & \\
\hline \multirow[t]{3}{*}{ TDTA } & Pearson Correlation & $-.768^{* *}$ & $-.445^{*}$ & $.937^{* *}$ & $.884^{* *}$ & 1 & \\
\hline & Sig. (2-tailed) & .000 & .011 & .000 & .000 & & \\
\hline & $\mathrm{N}$ & 32 & 32 & 32 & 32 & 32 & \\
\hline \multirow[t]{3}{*}{ FS } & Pearson Correlation & $-.833^{* *}$ & $-.731^{* *}$ & $.601^{* *}$ & $.672^{* *}$ & $.691^{* *}$ & 1 \\
\hline & Sig. (2-tailed) & .000 & .000 & .000 & .000 & .000 & \\
\hline & $\mathrm{N}$ & 32 & 32 & 32 & 32 & 32 & 32 \\
\hline
\end{tabular}

There is inverse association between EPS and STDTA and the association is significant. The association between LTDTA and EPS is significant and inverse. There is significant and inverse association between TDTA and EPS. ROA is inversely insignificant related to the STDTA. The association between ROA and LTDTA is inverse and significant. TDTA is also inversely related to the ROA and association is significant. The association between ROE and STDTA is inverse and insignificant but ROE is positively related to the LTDTA and TDTA and association is insignificant in both cases. Firm size is inversely related to the EPS and ROA and association is significant. The association between firm size and ROE is positive and insignificant. The association of firm size with STDTA, LTDTA and TDTA is positive and significant. 


\section{Regression Results}

This section is related with the hypothesis testing on the basis of two variables relationship and find the cause and effect between variables.

\section{Model}

In table 3 EPS is dependent variable while STDTA is an independent variable and firm size is control variable. There is inverse relationship between EPS and STDTA and the relationship is significant. There is also negative and significant relationship between firm size and EPS. R square of this model is 0.723 it means STDTA and firm size explained $72.3 \%$ to financial performance of transport sector.

Table 3: Results of Short Term Debt and Firm Size on Performance (EPS)

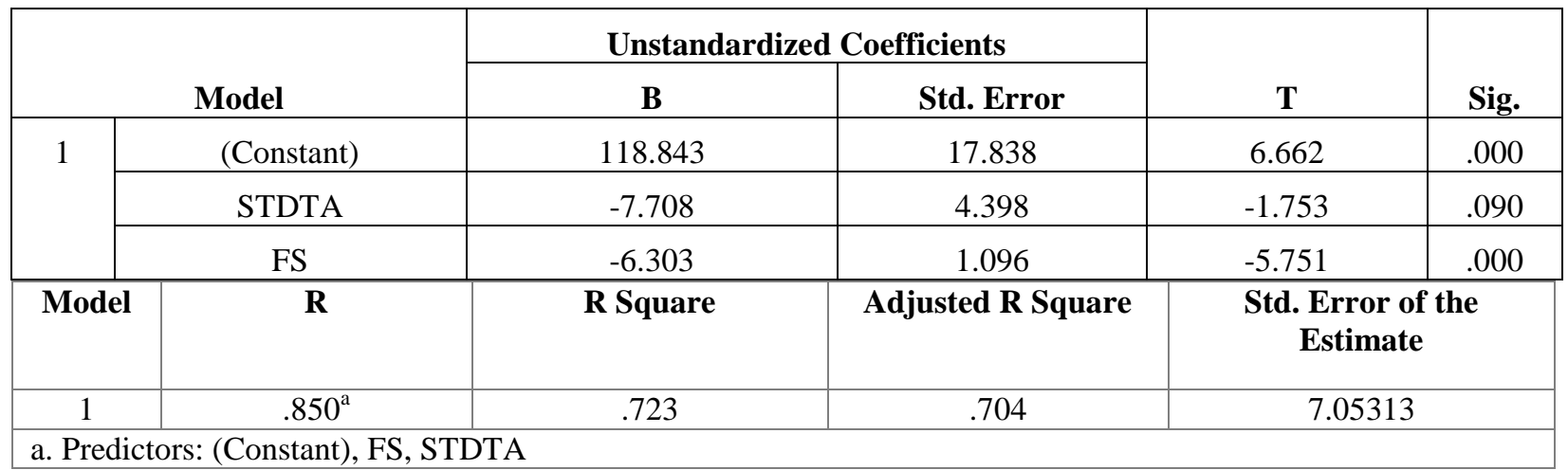

\section{Model 2}

In table 4 LTDTA is independent variable, firm size is control variable while EPS is dependent variable. There is negative relationship between FS and EPS and this relationship is significant. There is also adverse but significant relationship between EPS and LTDTA. R square of this model is 0.789 it means LTDTA and firm size explained $78.9 \%$ to financial performance of transport sector.

Table 4: Results of long term debt and firm size on performance (EPS)

\begin{tabular}{|c|c|c|c|c|c|}
\hline \multirow{2}{*}{\multicolumn{2}{|c|}{ Model }} & \multicolumn{2}{|c|}{ Unstandardized Coefficients } & \multirow[b]{2}{*}{$\mathbf{T}$} & \multirow[b]{2}{*}{ Sig. } \\
\hline & & B & Std. Error & & \\
\hline \multirow[t]{3}{*}{1} & (Constant) & 99.294 & 16.531 & 6.007 & .000 \\
\hline & FS & -4.942 & 1.032 & -4.789 & .000 \\
\hline & LTDTA & -20.157 & 5.558 & -3.627 & .001 \\
\hline Model & $\mathbf{R}$ & R Square & $\begin{array}{c}\text { Adjusted R } \\
\text { Square }\end{array}$ & \multicolumn{2}{|c|}{ Std. Error of the Estimate } \\
\hline 1 & $.888^{\mathrm{a}}$ & .789 & .774 & \multicolumn{2}{|c|}{6.15227} \\
\hline
\end{tabular}

\section{Model 3}

In table 5 TDTA is independent variable. TDTA is negatively related to the EPS and relationship is significant. Similarly there are negative but statistical significant relationships between firm size and performance. $\mathrm{R}$ square of this model is 0.764 it means TDTA and firm size explained $76.4 \%$ to financial performance of transport sector. 
Table 5: Results of total debt and firm size on performance (EPS).

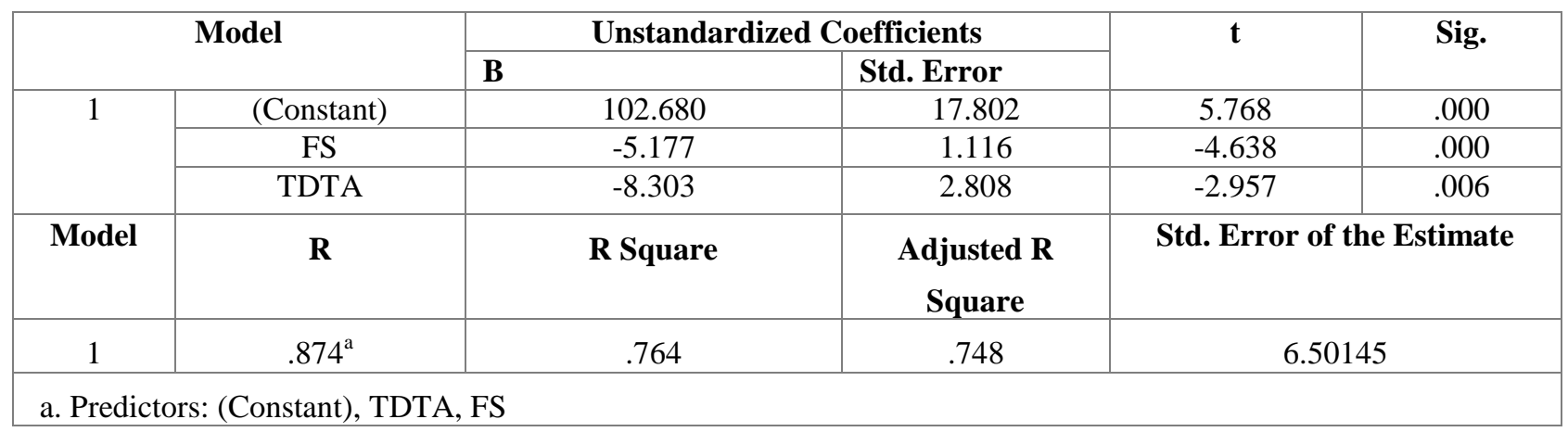

\section{Model 4}

In table 6 dependent variable is ROA while FS is control variable and STDTA is independent variable. ROA and firm size relationship is significant and negative but the positive and insignificant relationship between ROA and STDTA. R square of this model is 0.560 it means TDTA and firm size explained $56 \%$ to financial performance by return on total assets of transport sector

Table 6: Results of short term debt and firm size on performance (ROA).

\begin{tabular}{|c|c|c|c|c|c|}
\hline \multirow{2}{*}{\multicolumn{2}{|c|}{ Model }} & \multicolumn{2}{|c|}{ Unstandardized Coefficients } & \multirow[b]{2}{*}{$\mathbf{t}$} & \multirow[b]{2}{*}{ Sig. } \\
\hline & & B & Std. Error & & \\
\hline \multirow[t]{3}{*}{1} & (Constant) & 2.621 & .440 & 5.954 & .000 \\
\hline & FS & -.150 & .027 & -5.531 & .000 \\
\hline & STDTA & .142 & .109 & 1.312 & .200 \\
\hline Model & $\mathbf{R}$ & R Square & Adjusted R Square & \multicolumn{2}{|c|}{ Std. Error of the Estimate } \\
\hline 1 & $.748^{\mathrm{a}}$ & .560 & .530 & \multicolumn{2}{|c|}{.1741} \\
\hline
\end{tabular}

\section{Model 5}

In the table 7 Firm size and ROA relationship is significant and negative. LTDTA is also negatively related to the ROA and insignificant relationship. R square of this model is 0.538 it means LTDTA and firm size explained 53.8\% to financial performance of transport sector.

Table 7: Results of long term debt and firm size on performance (ROA).

\begin{tabular}{|c|c|c|c|c|c|}
\hline \multirow{2}{*}{\multicolumn{2}{|c|}{ Model }} & \multicolumn{2}{|c|}{ Unstandardized Coefficients } & \multirow[b]{2}{*}{$\mathbf{t}$} & \multirow[b]{2}{*}{ Sig. } \\
\hline & & B & Std. Error & & \\
\hline \multirow[t]{3}{*}{1} & (Constant) & 2.174 & .479 & 4.535 & .000 \\
\hline & $\mathrm{FS}$ & -.119 & .030 & -3.960 & .000 \\
\hline & LTDTA & -.078 & .161 & -.485 & .631 \\
\hline Model & $\mathbf{R}$ & R Square & Adjusted R Square & \multicolumn{2}{|c|}{ Std. Error of the Estimate } \\
\hline 1 & $.733^{\mathrm{a}}$ & .538 & .506 & \multicolumn{2}{|c|}{.1784} \\
\hline
\end{tabular}

\section{Model 6}

Table 8 shows the results that the connection between SIZE and ROA is significant but negative while the ROA is positively linked with the TDTA and relationship is insignificant. R square of this model is 0.541 it means TDTA and firm size explained $54.1 \%$ to financial performance of 
transport sector.

Table 8: Results of Total Debt and Firm Size on Performance (ROA).

\begin{tabular}{|c|c|c|c|c|c|}
\hline \multirow{2}{*}{\multicolumn{2}{|c|}{ Model }} & \multicolumn{2}{|c|}{ Unstandardized Coefficients } & \multirow[b]{2}{*}{$\mathbf{t}$} & \multirow[b]{2}{*}{ Sig. } \\
\hline & & B & Std. Error & & \\
\hline \multirow[t]{3}{*}{1} & (Constant) & 2.513 & .487 & 5.162 & .000 \\
\hline & FS & -.142 & .031 & -4.654 & .000 \\
\hline & TDTA & .050 & .077 & .657 & .516 \\
\hline Model & $\mathrm{R}$ & R Square & Adjusted R Square & \multicolumn{2}{|c|}{ Std. Error of the Estimate } \\
\hline 1 & $.735^{\mathrm{a}}$ & .541 & .509 & \multicolumn{2}{|c|}{.1778} \\
\hline
\end{tabular}

\section{Discussion}

In this section we will discuss the model fitness and check the overall significance of model. In model 1 EPS is dependent variable and STDTA is explanatory variable and FS is control variable. This model is good fit because $\mathrm{R}$ square is 0.723 and $71 \%$ variations in dependent variable(EPS) is explained by the independent variable(STDTA). LTDTA is independent variable in second model and it is also good fit model. R square is 0.789 which tells that $79 \%$ variations in EPS are due to explanatory variable and model is also overall significant. Similarly model with TDTA is also good fit and overall significant.

In model $4 \mathrm{ROA}$ is dependent variable and $\mathrm{R}$ square is only $56 \%$ but the model is overall significant. Only $56 \%$ variations in ROA is explained by STDTA. LTDTA has been taken as explanatory variable in model 5 and $\mathrm{R}^{2}$ is only $54 \%$ and significant model. Model 6 is also overall significant but $\mathrm{R}$ square is only 0.54 . The results of the study show that there is negative and significant relationship between EPS and all types of debt. There is also negative and significant relationship between firm size and EPS. The relationship between ROA and short term debt and total debt is positive and insignificant but with long term debt relationship is negative and insignificant. The relationship between firm size and ROA is negative and significant. Our study results matched with (Bratlie and Jotne, 2012) and Alahyari (2014) which also found inverse relationship between debt and profit. This study is very helpful for managers regarding taking decisions of debt financing and know about whether debt has increase the performance or not. This study is also useful for shareholders for their decisions regarding investment in airline industry.

\section{Conclusion of the Study}

The purpose of this study is to evaluate the relationship between debt financing and the profitability of transport companies. This study covers the period 2008 to 2018 and financial statements of companies used as a secondary source for data collection. Only 3 companies have been taken for analysis due to unavailability of data. Descriptive statistics show that $44 \%$ of short-term debt has been used to finance assets and $38 \%$ of long-term debt has been used to finance assets. So a lot of debt has been used for assets financing. The companies' major source of finance is banks which charge high rate of interest and demand the collateral and there is no market of long term debt in Pakistan. So inverse relationship between the performance of transport companies and debt. Higher the level of debt that causes the decline in the performance of the transportation industry. Companies must focus on the internal source of financing, which is the lowest cost option. Decisions related to the capital structure play an important role in improving the performance of companies in the transport industry.

\section{Policy Recommendations}

The recommendations of the study are as follows; 
- Companies should focus on internal source of finance due to least cost and reliable source of finance.

- There is a need to consider the optimal debt level in capital because as the level of debt increases the risk factor of insolvency increases.

- There is no need to increase the size of firms because it negatively affects the performance of companies in transport sector.

\section{Limitations and Future Research Direction}

There are some limitations in the study. Only three companies have been taken for analysis due to data unavailability and time period is only ten years. Most accurate results can be obtained by taking long period of time and taking more companies in the sample. But some airlines companies are not listed in stock exchange. In this research, only debt is used as independent variable but there are also other variables which can affect the performance of airline industry so these other independent variables also consider for future research. So future research can be conducted on this topic by considering the other variables and by increasing the time span and achieve the more reliable results. This research can be extended by comparing the transport industry of two countries.

\section{References}

Alahyari, A. (2014). Determinants of Profitability in the Airline Industry: A Comparison with Turkish Airlines (Doctoral dissertation, Eastern Mediterranean University (EMU)-Doğu Akdeniz Üniversitesi (DAÜ)).

Bjelicic, B., 2012. Financing airlines in the wake of the financial markets crisis. Journal of Air Transport Management, 21, pp.10-16

Bratlie, E. K., \& Jøtne, A. (2012). Capital structure in the airline industry: an empirical study of determinants of capital structure (Master's thesis).

Damodaran, A 2001, Corporate Finance: Theory and Practice, 2 nd edn, Wiley

Damodaran, A. 2001. Corporate finance: Theory and practice. New York: John Wiley and Sons.

Frank, M. \& Goyal, V. (2007). Capital Structure Decisions: Which Factors are Reliably Important?

Gaud,P., Hoesli, M., \& Bender , A. (2005). The capital structure of swiss companies: an Empirical analysis using dynamic panel data. European financial management Volume 11, issue 1, 51-69.

Khazaaleh (2017) Capital Structure in the Airline Industry- An empirical study of determinants of capital structure

Modigliani, F. and M.H. Miller, (1958), the Cost of Capital, Corporation Finance, and the Theory of Investments, American Economic Review 48, 261-297.

Modigliani, F. and Miller, M. (1963), corporate income taxes and the cost of capital: a correction, American Economic Review, 53, 443-53.

Pandey, I.M (2010). Financial Management, Tenth Edition, Vikas Publishing Home PVT Ltd, New Delhi.

Psillaki, M., \& Daskalakis, N. (2009). Are the determinants of capital structure country or firm specific? Small Business Economics, 33(3), 319-333.

Titman, S., \& Wessels, R. (1988). The Determinants of Capital Struture Choice. The Journal of Finance, 43(1), 1-19.

Tomoiagă, I. C. (2014). The effect of capital structure on airline's value. 